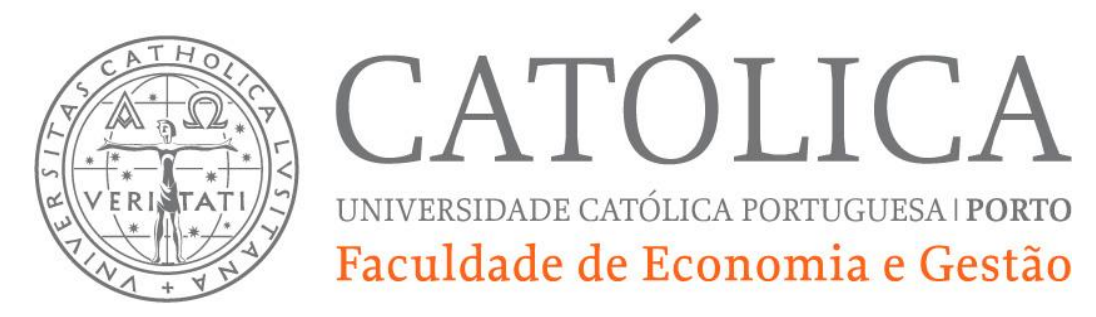

$$
N^{\circ} 04 / 2014
$$

\title{
THE ECONOMICS OF STRUCTURED LEASING
}

\author{
João Pinto \\ Universidade Católica Portuguesa (Porto) \\ Luís K. Pacheco \\ Universidade Católica Portuguesa (Porto)
}




\title{
THE ECONOMICS OF STRUCTURED LEASING
}

\author{
João M. Pinto* \\ Professor of Finance \\ School of Economics and Management \\ Catholic University of Portugal - Porto \\ e-mail: jpinto@porto.ucp.pt
}

Luís K. Pacheco

Professor of Finance

School of Economics and Management

Catholic University of Portugal - Porto

e-mail: 1pacheco@porto.ucp.pt

Working Paper

First Draft: November 2013

Current Draft: May 2014

Comments Welcome

Please do not quote or cite without permission

* The authors thank Álvaro Nascimento, Mário Santos, Manuel Marques, Miguel Ferreira, and William Megginson for helpful comments on earlier drafts.

Please address all correspondence to:

João M. Pinto

Católica Porto Business School

Rua Diogo Botelho, 1327

4169-005 PORTO

Tel: (00351) 226196260

e-mail: jpinto@porto.ucp.pt 


\begin{abstract}
A structured leasing is a new and highly flexible transaction that develops synergies between funding policy, risk management of the underlying assets, and tax benefits. It is used in particular transactions involving complex and large-scale assets, such as airplanes, ships, industrial plant and equipment, and large real estate projects.

As in other tax-based techniques, the implementation of a structured leasing transaction, either a leveraged lease or a synthetic lease, is more significant when the value of the asset is large and allows for a potentially greater tax benefits' appropriation.

Structured leasing creates value by increasing liquidity and funding, reducing the funding costs, allowing sponsors to attain greater leverage and to increase tax shields, improving lessees' risk management, and allowing lessees to maintain financial flexibility, by improving or maintaining financial ratios.

Although all of the above-mentioned economic advantages, structured leasing also has problems. The most commonly referred problems of structured leases are complexity, offbalance sheet treatment, higher transaction costs, and wealth expropriation.

Besides describing the economic motivations and problems of structured leasing, this paper provides details on the characteristics of structured leasing activity and reviews the most influential papers, summarizes their results, and associates them with the existing empirical evidence.
\end{abstract}

Key words: leasing, structured leases, leveraged leases, synthetic leases.

JEL classification: G23; G24; G32 


\section{Introduction}

The literature on structured leasing is scarce when compared to other fields of corporate finance. In fact, neither in academic nor in professional literature can systematic studies be found dealing with the positioning of both researchers and economic agents in the market (financial intermediaries). Similarly, there is little discussion of structured leasing in leading corporate finance textbooks. Given the growing importance of structured leasing as a new financing instrument, corporate executives, bankers, lawyers, investors, government officials, and academics need to understand what structured leasing is, why and how it may create value, and how to structure transactions with both operational and financial success.

Used in particular transactions involving complex and large-scale assets, such as airplanes, ships, industrial plant and equipment, and large real estate projects, a structured leasing transaction can fall within one of the following two categories: $(i)$ leveraged transactions (mainly cross-border leasing with a trust); and (ii) synthetic leasing. A structured leasing is understood as a transaction that develops synergies between funding policy, risk management of the underlying assets and tax benefits. With these types of transactions, the sponsor aims to manage the need for funding in a creative manner, as opposed to just raising funds by means of recourse to the leasing instrument. Thus, structured leasing is a highly flexible tool. This idea is corroborated by Caselli (2005), who points out that a structured leasing, “... inasmuch as a leasing transaction can: (i) enable contract terms to be modulated in relation to the lessee's cash flow structure; (ii) generate governable tax benefits, with a different sequence and structure than is achieved by depreciating the asset and covering attendant financial costs arising from the funding policy adopted to purchase the asset; (iii) finance the possible call option at the end of the leasing transaction."1

In the following sections, we discuss structured leasing literature based on the central economic benefits as well as on the major problems related to the use of these financing instruments. Our goal is to review the most influential papers, summarize their results, present their relationship to each other, and associate them with the existing empirical evidence. Furthermore, the main objective of this paper is to analyze the basic characteristics of structured leasing activity and to answer the following questions: (i) What is a leasing transaction?; (ii) What are the basic characteristics of a structured leasing transaction?; and (iii) What are the economic motivations and problems of structured leases?

\footnotetext{
${ }^{1}$ See Carretta and De Laurentis (1998) for a review of leasing transactions. For a comprehensive account of theoretical and empirical literature on structured leasing see, among others, Braund (1989), Slovin, Sushka and Polonchek (1990), Fowkes (2000), Caselli (2005), Fabozzi, Davis and Choudhry (2006), and Deo (2009).
} 


\section{What Is a Leasing Transaction?}

Fabozzi, Davis and Choudhry (2006) define leasing as “... a contract over the term of which the owner of the equipments permits another entity to use it in exchange for a promise by the latter to make a series of payments. The owner of the equipment is referred to as the lessor. The entity that is being granted permission to use the equipment is referred to as the lessee." Based on the idea that earnings are originated from the use of an asset, not its ownership, leasing is commonly considered as an alternative method of financing. Leasing can and has been used to finance all types of assets including, but not limited to, industrial facilities (e.g., manufacturing and power generation), real estate (e.g., office, warehouse, and retail locations), and equipment (e.g., manufacturing and transportation). Thus, nearly asset that can be purchased can also be leased, from aircraft, ships, satellites, computers, refineries, and steamgenerating plants, on one hand, to typewriters, duplicating equipment, automobiles, and dairy cattle, on the other hand [Fabozzi et al. (2006) and Fowkes (2000)].

It is possible to identify the following steps in the design of a leasing transaction: $(i)$ the lessee identifies the equipment needed, the model and the manufacturer; (ii) the lessee defines the features desired in terms of warranties, installation, services, etc.; (iii) the lessee defines the price; (iv) the lessee enters into a lease agreement with the lessor, in which they define the length of the lease, the rental, if installation charges should be included in the lease, and other optional characteristics; $(v)$ the lessee assigns its purchase rights to the lessor, who buys the equipment as specified by the lessee; (vi) the lessor pays the price for the equipment and the lease enters into effect; (vii) at the end of the contract, the lessee usually has the option to renew the lease, to buy the equipment, or to terminate the agreement and return the equipment. The option selected by the lessee defines $(i)$ the lease nature for tax purposes, and (ii) the lease classification for financial accounting purposes.

Equipment leases can be classified as (A) Nontax-Oriented Leases or Tax-Oriented Leases; (B) Single-Investor Leases or Leveraged Leases; and (C) Full Payout Leases or Operating Leases. ${ }^{2}$

If a lease transaction is classified as a conditional sale lease or nontax-oriented lease: (i) all of the benefits and risks are substantially transferred to the lessee; (ii) the purchase or renewal option is not based on fair market value of the equipment at the time of exercise - is always lower; (iii) the lessee depreciates the property (treated as owned) for tax purposes; (iv) the lessee deducts the interest portion of the lease payments as an expense; and ( $v$ ) the lessor treats the transaction as a loan. Conversely, if a lease transaction is classified as a tax-oriented true lease: $(i)$ the lessor claims and retains tax benefits resulting from equipment ownership depreciation cost deduction; (ii) the lessor transfers to the lessee a portion of those benefits in

\footnotetext{
${ }^{2}$ For a further discussion of lease typologies see, among others, Caselli (2005) and Fabozzi et al. (2006).
} 
the form of reduced lease payments - via interest rate (or credit spread) reduction; (iii) the lessee deducts the full lease payment as a cost; (iv) the lessor owns the leased equipment at the end of the lease term - the lease contract has no purchase option or a purchase option based on the market value. Thus, in a nontax-oriented lease the lessor cannot offer the low lease rates associated with a true lease because the lessor does not retain the tax benefits available to the owner of the equipment. ${ }^{3}$ This idea is corroborated by Fabozzi et al. (2006), who argue that "[T]he principal advantage to a lessee of using a true lease to finance an equipment acquisition is the economic benefit that comes from the indirect realization of tax benefits that might otherwise be lost because the lessee cannot use the tax benefits. This occurs when the lessee neither has a sufficient tax liability, nor expects to be able to fully use the tax benefits in the future if those benefits are carried forward." One of the mostly common motivations for using structured leasing is the possibility of the lessee to obtain a lower funding cost vis-a-vis borrowing directly from a financial institution. This reduction comes from the fact that when the lessee is unable to generate a sufficient tax liability to currently use all tax benefits, the cost of owning the equipment is higher than leasing it.

Single-investor leases and leveraged leases are two categories of true leases. The first category is a two-party transaction in which the lessor purchases the leased equipment with its own funds. A leveraged leasing is similar to a single-investor lease - in terms of equipment selection and negotiation (rentals, options, responsibility for taxes, insurance, and maintenance) - but with a lower cost of funding, when compared to other methods of finance, and appreciably more complex in size, documentation, legal involvement, and, most importantly, the number of parties involved and the unique advantages that each party gains. Usually offered by corporations and financial institutions (tax benefits available to individual lessors are more limited), in a leveraged lease the lessor - which provides only $20 \%$ to $30 \%$ of the capital needed to purchase the equipment and the remainder is borrowed from institutional investor on a nonrecourse basis to the lessor - claims all of the tax benefits related to the ownership of the equipment and offers the lessee much lower lease rates when compared to single-investor leases [see, e.g., Fabozzi et al. (2006)].

Full payout leases, in contrast to operating leases, are basically financing transactions. An operating lease transaction is a true sale lease for tax purposes and thus the lessee can deduct the lease payments and the lessor is entitled to all tax benefits related to the equipments' ownership. For financial accounting purposes, an operating lease is not disclosed in the lessee balance sheet as financial obligations - the lease equipment is not capitalized and the lease

\footnotetext{
${ }^{3}$ For example, in the U.S., the Internal Revenue Code (IRC) establishes requirements for a lease to be treated as a true sale. The distinction between tax-oriented and nontax-oriented true leases is the type of purchase option - conditional sale leases have nominal fixed-price options while true leases have marketvalue purchase options.
} 
obligation is not shown as a liability on the balance sheet. ${ }^{4}$ However, the lessee must disclose information about the lease transaction on footnotes to its financial statements. An operating leasing transaction in theory has a greater 'tax acceleration' than financial leasing.

While there is an extensive literature on leasing, most of it focuses on the differential tax position of the lessee and the lessor as the primary rationale for leasing [e.g., Bower (1973), Miller and Upton (1976), Brealey and Young (1980), Smith and Wakeman (1985), and Brick, Fung, and Subrahmanyam (1987)]..$^{5}$ Miller and Upton (1976) conclude that no financial advantages accrue from leasing. Contrary, Lewellen, Long, and McConnell (1976) and Myers, Dill, and Bautista (1976) argue that, under a set of assumptions, there is a potential for gains in valuation for the firm involved in leasing because government can suffer a loss in taxes. Graham, Lemmon and Schallheim (1998) show a negative relationship between operating leases and tax rates, and a positive relationship between debt levels and tax rates. Eisfeldt and Rampini (2009) argue that the benefit of leasing is that the repossession of leased assets is easier than foreclosure of secured loans. Lease financing has an advantage over straight debt and even secured debt in that it has a stronger financial claim, being effectively senior to any other financial claim.

Some authors study the debt versus leasing decision. Ang and Peterson (1984) failed to demonstrate that debt and leasing are substitutes and found instead a complementary relationship. Although Lewis and Schallheim (1992) found similar results, Marston and Harris (1988), and Adedeji and Stapleton (1996) support substitutability. More recently, Mehran, Taggart and Yermack (1999) presented a mixed evidence and Beattie, Goodacre and Thomson (2000) argue that leasing and debt are partial substitutes. ${ }^{6}$

\section{Basic Characteristics of Structured Leasing Transactions}

Structured leasing is a specific and recent type of transaction, confirmed by the fact that references to it have only appeared recently. As pointed out by Caselli (2005) “... structured leasing was recognized as new transaction and an independent form of leasing within the structured finance and asset finance sector." Additionally, banks and sponsors try to protect their expertise in the sector, believed to offer a competitive advantage.

\footnotetext{
${ }^{4}$ For accounting purposes, a lease can be classified as either an operating lease or a capital lease. According to FASB Statement No. 13 "[A] lease that transfers substantially all of the benefits and risks incident to ownership of property should be accounted for as the acquisition of an asset and the incurrence of an obligation by the lessee." Thus, all other leases should be accounted for as operating leases. FAS 13 specifies that if one of the following four criteria are met for a noncancelable lease at the date of the lease agreement, the lease is to be accounted for as a capital lease: $(i)$ the lease transfers ownership of the property to the lessee by the end of the lease term; (ii) the lease contains a bargain purchase option; ( iii) the lease term is equal to $75 \%$ or more of the estimated economic life of the leased property; and (iv) the present value of the minimum lease payments (excluding executor costs) equals or exceeds $90 \%$ of the fair value of the leased property.

${ }^{5}$ Krishnan and Moyer (1994) present a very concise and complete literature review on this subject.

${ }^{6}$ See Braund (1989) for a review of the empirical studies on leasing.
} 
It is a very versatile instrument that enables the lessee to position the deal in an optimal manner in relation to cash flow structure, its sustainability over time and the distribution of tax benefits. A key feature of structured leasing transactions, which differentiates them from other financing arrangements, is the presence of a separate vehicle company (SPV or SPE) incorporated to take the initiative and hold the leased asset(s) and to secure cash receipts and the resulting payments.

As in other tax-based techniques, the implementation of a structured leasing transaction is more significant when the value of the asset is large and allows for a potentially greater tax benefits' appropriation. Considering the nature and the role of the asset, which affects the financial flows and risk set-up for the transaction, we can identify diverse structured leasing transactions. Thus, bearing in mind the asset nature in terms of product category, real estate can be residential, administrative, commercial, industrial or infrastructural. In terms of the asset nature, from a legal point of view, it can already exist and be owned by the lessee, can already exist and be owned by a third party, or may even not yet be built. The next figure provides a map of possible structured leasing transactions, where we overlap the two mentioned perspectives.

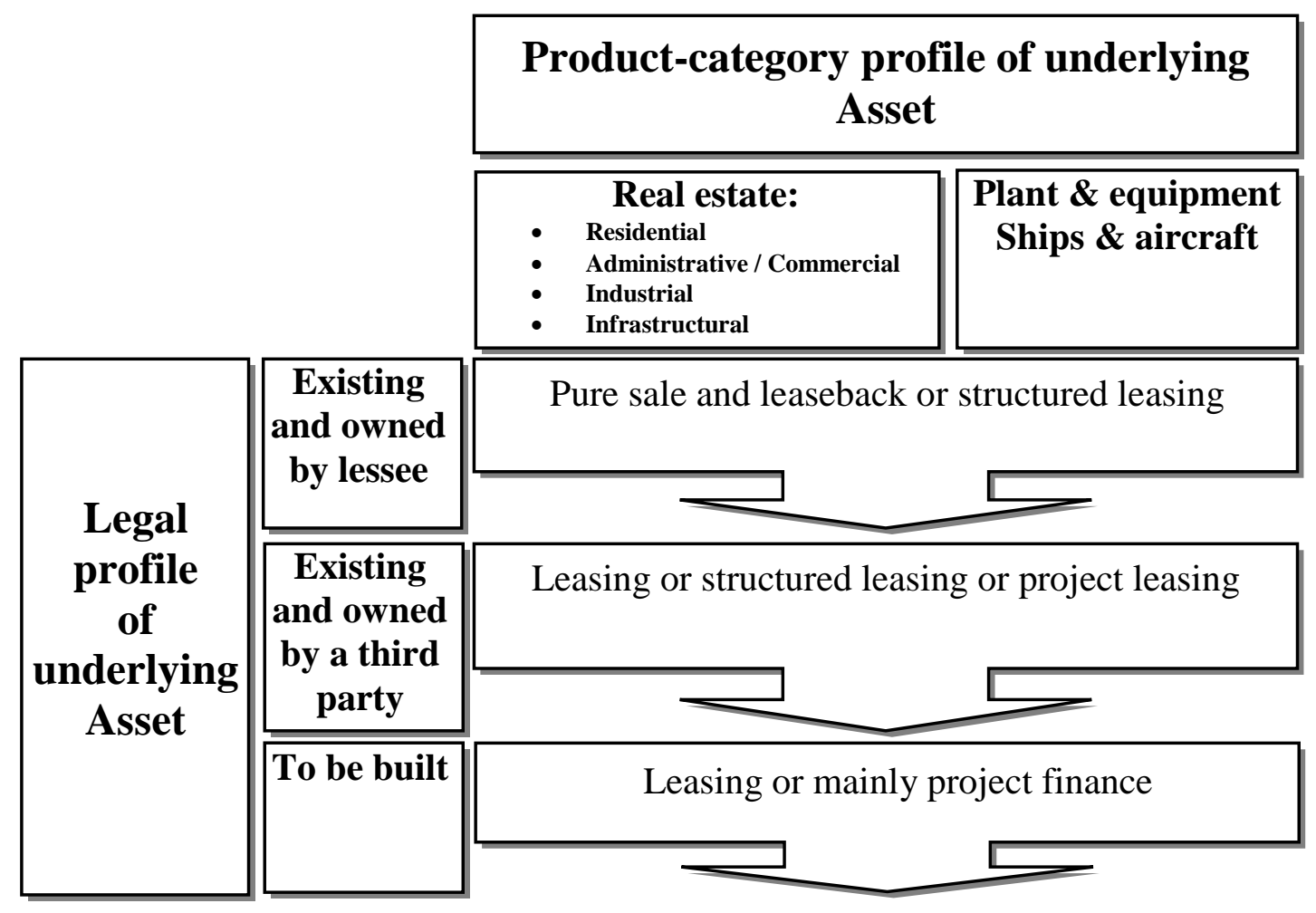

Source: Adapted from Caselli (2005).

As asserted by Caselli (2005), “... while the asset's product category heavily conditions the nature and intensity of financial and equity risks associated with the transaction, the legal profile, if the asset already exists, conditions the financial structure and overall arrangement of 
the transaction itself." Contrary to commercial, industrial, and infrastructural real estate, and above all industrial plant and equipment, residential, and to a degree, administrative real estate, ships and aircraft represent, ceteris paribus, a lower financial and equity risk because they tend to have a better defined market value - the secondary market for this assets is wider. This analysis in relation to legal profile and product-category profile can be extended, by considering size and whether the deal is of a domestic or of cross border nature. ${ }^{7}$

Considering the existing literature, structured leasing transactions can fall within one of the two following categories: (i) leveraged leases (or tax or true leases); and (ii) synthetic leases (or synthetic structured leases). The increased tax benefits afforded by operating leasing have provided a strong stimulus to create 'structured' transactions that give operating leasing the same characteristics as true financial leasing. The so-called synthetic leasing transactions.

A leveraged lease (a true lease) is similar to a single-investor lease (also called nonleveraged leases or direct leases) but more complex in size and in the number of involved parties - it involves a minimum of three parties with diverse interests: a lessee, a lessor, and a nonrecourse lender. ${ }^{8}$ In a leveraged lease (sometimes called a three-party transaction) the lessor becomes the owner of the leased equipment by providing a fraction of the capital necessary to purchase the equipment. The rest of the capital (70\% to 80\%) is borrowed from institutional investors on a nonrecourse basis to the lessor. As asserted by Fabozzi et al. (2006), in a leveraged lease the largest part of the "... debt is raised on the private placement market at little or no premium over what the lessee would expect to pay directly for such debt. The sources include insurance companies; pension plans; profit-sharing plans; commercial banks; finance companies; saving banks; domestic leasing companies; foreign banks; foreign leasing companies; foreign investors; and institutional investors."

The lease all-in cost varies with the credit standing of the lessee and with the risk of the transaction. A guarantor of the lessee obligations - a lessees' parent or sister company, a third party, or a government agency - may be necessary if the credit of the lessee is insufficient to support the transaction.

The 'leverage' in leveraged leases comes from the fact that: $(i)$ the lessor provides only $20 \%$ or $30 \%$ of the capital needed to purchase the equipment and stay at risk only for that portion; (ii) the lessor can claim all of the tax benefits related to ownership - a leveraged lease is always a true lease; and (iii) the lessor has the right to $100 \%$ of the residual value provided by the lease. ${ }^{9}$ It is this leverage that allows the lessor to offer the lessee a lower lease rate than the

\footnotetext{
${ }^{7}$ See Caselli (2005) for a further discussion of the structured leasing transaction market, with a focus on the European market.

${ }^{8}$ See, e.g., Shank and Gough (1999), Amembal (2000), Boobyer (2003) and Deo (2009) for further discussion of the economics of leveraged leasing.

${ }^{9}$ See Fabozzi et al. (2006) for a description of the various steps and milestones in structuring, negotiating and closing leveraged lease transactions.
} 
lessor could offer under a nonleveraged lease or direct lease - the equity investor passes a portion of his tax benefit back to the lessee in the form of reduced lease payments. ${ }^{10}$ Leveraged transactions tend to be used in markets offering specific tax advantages to leveraged leasing transactions. Caselli (2005) argue that "[T]his occurs mainly in two different situations: in international cross-border leasing, and when trusts are used."

Cross-border leasing refers to German (GELL - German Leveraged Leasing), French (FDDL - French Double Dip Leasing), US (USPL - US Pickle Leasing), and UK (BDDL British Double Dip Leasing) markets where its use offers specific tax advantages to the lessor, making the transaction more attractive both for the foreign lessee and for potential financiers of the leveraged transaction, who can 'participate in' the increased tax benefits produced by the deal. Cross-border leases have become a source of financing for European Companies. The U.S. Cross-border lease (closed on a variety of assets) is structured to benefit from tax arbitrage between US and an European Lessee [see, e.g., Wanzenboeck (2001)]. When the leasing is structured based on the interposition of a trust between the lessor and lessees the tax benefits produced are duplicated - nowadays it is possible to identify the Trust Leasing and the Japanese Leveraged Leasing. ${ }^{11}$

When a sponsor is facing low expected marginal tax rates, a leveraged leasing may provide the lowest after-tax cost of funding. Additionally, if a sponsor cannot efficiently use the maximum depreciation or interest deduction benefits associated with tax ownership of assets, an institutional equity investor who can efficiently use these benefits may be willing to give back a portion of these benefits to the sponsor in the form of lower lease payments. Thus, lessees who foresee that they may not be able to use the tax benefits of ownership (e.g., tax depreciation) generally tend to use leveraged leases.

Having in mind that, in a leveraged lease, the lessee selects the assets, enjoys the benefits from their use - although it loses the tax benefits - and enjoys the lower lease rates. Exhibit 1 depicts the activities and cash flows involved. The main steps in the implementation of a leveraged leasing transaction are: Step 1 - the lessor establishes an SPV or a Trust, usually a bank, also known as the owner trustee or equity trustee; Step 2 - the lessor makes an equity investment (typically $20 \%$ or more of the purchase price) in the SPV; Step 3 - the lessee assigns the purchase agreement to the owner trustee; Step 4 - the trust borrows the remaining $80 \%$ or less from lenders; ${ }^{12}$ Step 5 - the lessor purchases the asset with $100 \%$ funding (a mix between

\footnotetext{
${ }^{10}$ In a large leverage lease - several owners and lenders are involved - an owner trustee is usually constituted to hold title to the equipment and represent the owners or equity participants.

${ }^{11}$ See, e.g., Deo (2008) for an explanation of Cross-border Japanese Leveraged Leases.

12 As referred by Deo (2009), the borrowing process is "... accomplished as follows: the lenders select a trustee (usually a bank), also known as an indenture trustee or loan trustee; on behalf of the lender, the indenture trustee issues a loan to the owner trustee..." The loan has the following characteristics: $(i)$ is secured by a mortgage of the asset; (ii) the income from the lease is assigned to the indenture trustee; and (iii) a guarantee of payment may be issued by the lessee.
} 
equity and debt) from the manufacturer; Step 6 - the lessor becomes the owner of the asset; Step 7 - the lessee is being granted the permission to use the asset; and Step 8 - the lessee makes a series of payments, the lease payments.

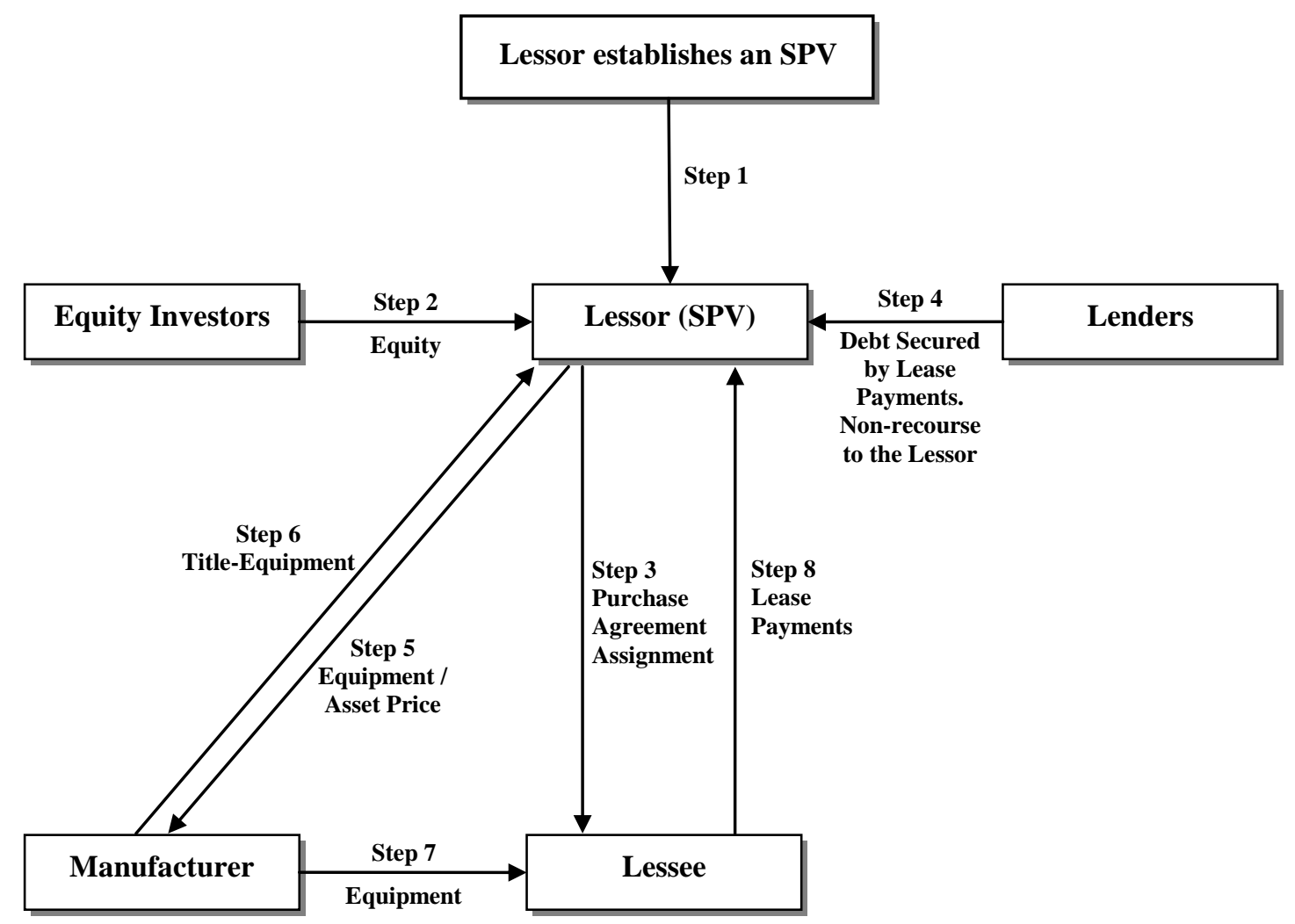

Exhibit 1: Activities and cash flows involved in a Leveraged Lease. Source: The Authors.

However, one of the drawbacks of a true sale of equipment for many lessees is the possible loss to be experienced when the true lease terminates and the equipment may have to be acquired from the lessor [Fabozzi et al. (2006)]. The synthetic lease was developed to solve this limitation, by providing at the same time off-balance sheet treatment of the lease obligation and protecting the lessee's cost of acquiring the equipment when lease terminates. Weidner (2000) defines synthetic lease as a "... method used to provide off-balance sheet financing to a corporate entity for the acquisition and development of a commercial facility or site, with substantial credit support for debt issued by or through an investor or capital source, usually a financial institution." A Synthetic lease transaction if typically structured using an SPV that is created solely for the purpose of a transaction or into a series of transactions.

Synthetic leases are operating leases for accounting purposes and financing operations for tax purposes; i.e., they are off-balance sheet leases, in which the lessee remains the owner of the financed assets and retain the tax benefits associated with ownership, while simultaneously enjoying the benefits of an operating lease. To be classified as an operating lease, a synthetic 
lease is structured on the basis of a lease agreement between the lessee (as the user or owner) and the lessor (as an investor), which complies with the requirements established by FAS 13 and related accounting rules. For tax purposes, a synthetic lease is structured so that the lessee may reclaim that it is, in substance, the owner of encumbered property, with a rental obligation that should be treated as debt service. Additionally, the lessee claims a depreciable interest in the asset and a depreciable basis that includes the portion of the cost financed with borrowed funds. ${ }^{13}$

As previously referred, a synthetic leasing transaction is based on the establishment of an SPV exclusively for the transaction. This means that the SPV is the owner of the asset / equipment, which then proceeds to organize the leasing with the lessee and to raise the funding, needed to purchase the asset itself. According to Caselli (2005), the motivations behind synthetic leasing are: “... a search for countries in which to domicile the SPV enabling greater tax benefits to be obtained than in the country of origin; the optimization of tax benefits by transforming financial leasing into operating leasing."

In the first motivation, the SPV's income statement will comprise: (i) depreciation of the asset; (ii) financial costs for servicing the debt; and (iii) installments received from leasing contracts. The lessee will select the most advantageous country from a tax treatment point of view, in which there is a significant difference between installments received by the SPV and the depreciation of the asset. Thus, the lessee can reduce the transaction all-in cost.

In the second case, the use of an SPV is justified (apart from the reasons referred for the first case) to implement an operating leasing than a financial leasing and, consequently, increasing the tax benefits from the transaction. This is particularly relevant when the lessee wants to set up an off-balance sheet transaction to improve its structural margin. This idea is corroborated by Fowkes (2000), who states that "[S]ynthetic leasing may be the most costeffective option for lessees with high marginal tax rates."

Exhibit 2 depicts the activities involved in a synthetic lease structure. The core steps in the execution of a synthetic lease transaction are: Step 1 - the SPV is incorporated; Step 2 - the lessor, together with the lessee (typically a very small part of the SPV's equity), makes an equity investment in the SPV; Step 3 - the SPV borrows the remaining from lenders; ${ }^{15}$ Step 4 the SPV purchases the asset price from the supplier; Step 5 - the lessor becomes the owner of the asset; Step 6 - the SPV signs a leasing contract with the lessee giving the permission to use the asset; Step 7 - the lessee makes a series of payments, the lease payments; Step 8 - the SPV

\footnotetext{
${ }^{13}$ Especially in the early years of the financing arrangement, the combined depreciation and interest deductions typically exceed the rental deduction.

${ }^{14}$ Altamuro (2006) asserts that the proponents of synthetic lease argue that economic benefits outweigh the costs of complexity and opacity, while critics argue that the economic benefits of these off-balance sheet transactions "... are the result of short-sighted opportunistic behavior by managers that lead to wealth extraction at the expense of other groups of stakeholders."

${ }^{15}$ The Lenders can fund the debt capital by a direct loan made through a pool or by issuing bonds.
} 
uses the periodic installments to repay the lenders; and Step 9 - the lessee exercises the call option on the asset or on the SPV shares. At the end of the transaction the lessee may, if it wishes, exercise the call option on the asset owned by the SPV or on shares in the SPV, so becoming the owner.

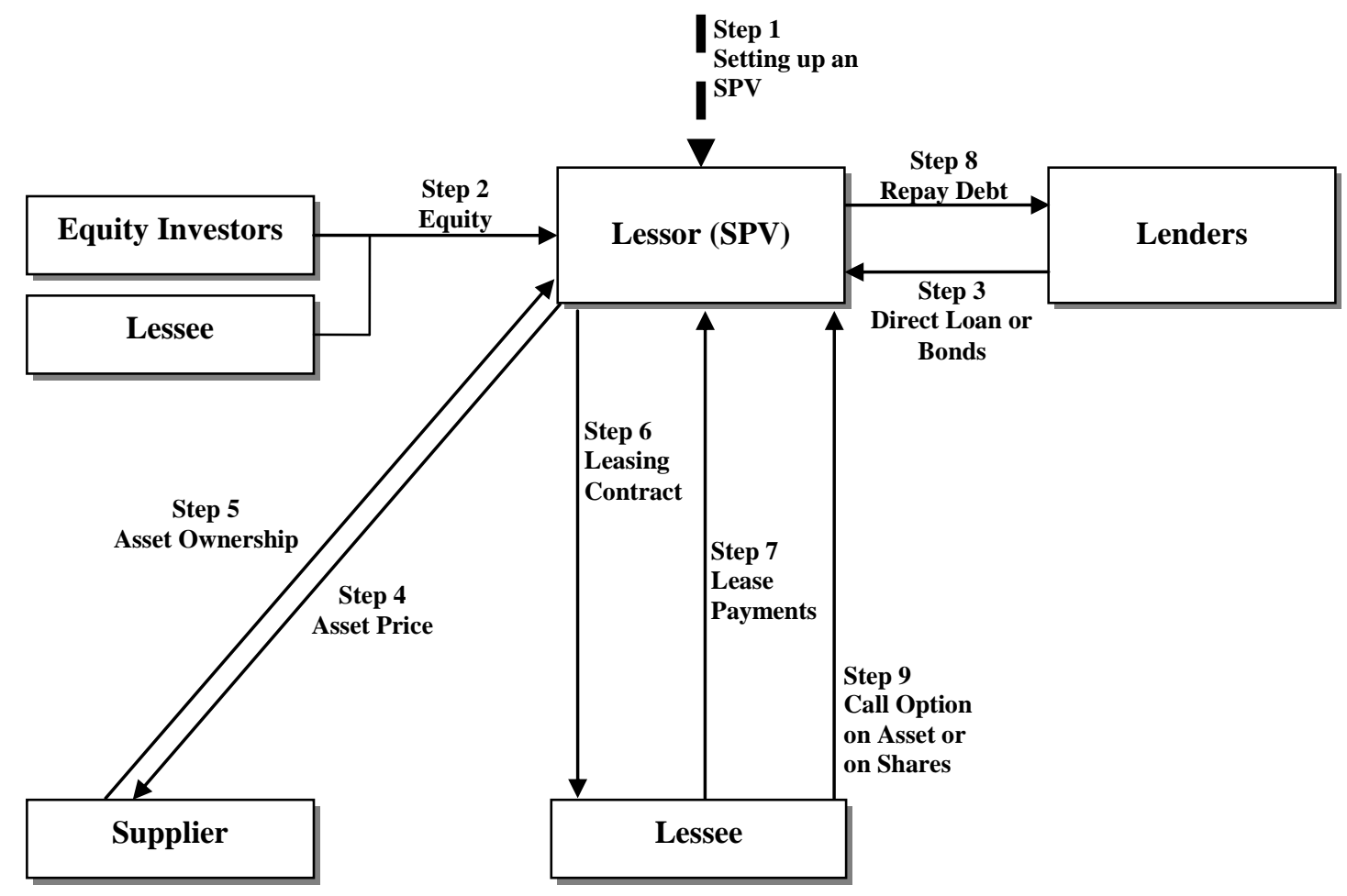

Exhibit 2: activities and cash flows involved in a Synthetic Lease. Source: The Authors.

Fowkes (2000) summarizes the two types of structured leasing in a very concise way. He argues that with a leveraged lease, which is structured as a lease for tax purposes, the tax benefits of depreciation and interest deduction are retained by the lessor but partially passed back to the lessee through lower rents. A synthetic lease is an operating lease for accounting purposes but structured as a financing for tax purposes. Both use an SPE to act as an owner (or lessor) of the assets, and achieve off-balance sheet operating lease treatment for the lessee under FAS 13.

\section{The Economic Motivations for Using Structured Leasing}

The results of Modigliani and Miller (1958) and of subsequent authors ${ }^{16}$ that, under a specific set of restrictive and artificial assumptions - when markets are complete - the capital structure decision of firm was irrelevant to its market valuation, suggests that the design of securities and financing transactions in this case is also irrelevant. However, the result that capital structure effectively matters in a world where market frictions and imperfections are

\footnotetext{
${ }^{16}$ Such as Stiglitz (1969, 1974), Baron (1974, 1976), and Hellwig (1981).
} 
present indicates that the design of securities and financing transactions may also be important. This throws light on the optimal design of securities and on the development of structured leasing transactions. Thus, research needs to focus on market imperfections to understand what are the economic motivations of structured leases.

The literature on structured leasing suggests several possible economic motivations. The first relates to the fact that structured leasing enables the financing of a particular asset class when established forms of external finance are unavailable for a particular financing need. Beattie et al. (2000) argue that poor liquidity and cash flow have significant influence over leasing decisions. ${ }^{17}$ They conclude that structured leasing is usually used by firms using complex and large-scale assets and who face liquidity and cash flow constrains. The authors argue that "... the characteristics of a firm's current and future assets, and in particular asset specificity, can influence financing." The same line of reasoning is presented by Smith and Wakeman (1985), Williamson (1988), Krishnan and Moyer (1994), and Barclay and Smith (1995). According to Krishnan and Moyer (1994), “... firms with greater financial distress potential and high debt leverage, ceteris paribus, may find financing alternatives to leasing unavailable." Thus, when bankruptcy probability increases, lease financing becomes a more attractive financing option as it offsets the higher transaction costs that are usually associated with lease agreements versus secured debt agreements.

The second economic benefit is a reduction in funding costs, when the benefits of the reduced cost of funding are greater than the cost of the required credit enhancement. Comparing leasing with purchasing using borrowed funds, Fabozzi et al. (2006) present funding cost reduction via tax benefits as one of the major economic forces behind structured leasing. Structured leasing provides the option of 'selling' tax allowances to a lessor, in exchange for lower rental payments. In a tax-oriented transaction, the lease is treated as a true sale for tax purposes, so that tax benefits of ownership can be transferred to the lender. This is crucial in a true sale lease transaction, where a lessee cannot use tax benefits associated with equipment ownership due to the lack of currently taxable income or net carryforwards of operating loss. ${ }^{18}$ According to Caselli (2005), “... the tax variable becomes a powerful tool for creating economic maneuvering room to reduce the cost of capital for its users." Capturing tax benefits means taking advantage of the differences in tax treatment between leasing and other forms of

\footnotetext{
${ }^{17}$ Beattie et al. (2000) present the following four major determinants of leasing: (i) industry sector is a significant explanatory factor for the level of leasing; (ii) firm size has a different influence on the choice between leasing and other forms of debt finance - small companies may prefer leasing over debt; (iii) tax considerations is an important factor in the choice between debt and leasing; and (iv) poor liquidity and cash flow have significant influence over the decision of leasing.

${ }^{18}$ Lease payments from leasing rather than borrowing are lower if a lease transaction is properly structured in a way that the lease will be treated as an operating lease for financial reporting purposes and as a true lease for tax purposes. A synthetic lease is a type of structured leasing transaction that meets this need while avoiding one of the drawbacks of a true lease for many lessees: the possibility of loss when the true sale lease terminates and the equipment may have to be acquired from the lessor.
} 
financing with the aim of reducing the lessee's cost of capital - reduction of the all-in cost. ${ }^{19}$ Additionally, Eisfeldt and Rampini (2009) argue that the benefit of leasing is that the repossession of leased assets is easier than the foreclosure of secured loans; i.e., lease financing has an advantage over straight debt and even secured debt, as far as it offers a stronger financial claim, being effectively senior to any other financial claim. ${ }^{20}$ Referring to the use of leasing in project financing, Fowkes (2000) argues that true leases may provide an alternative source of funding at a lower cost; i.e., in a leveraged lease (or tax or true lease) the lessee forgoes tax depreciation benefits but negotiates lower lease rates with the lessor. Altamuro (2006) shows that synthetic leases provide an economic benefit for the lessee in the form of lower direct financing costs. The author finds that synthetic lease firms receive more favorable interest rates on future syndicated loans. ${ }^{21}$ The minimization of bankruptcy risks for the bank or leasing company, compared to traditional real estate loan, is commonly presented as an effective benefit for lenders which is reflected in the borrower all-in cost.

Structured leasing also allows the borrower to attain greater leverage, compared to senior unsecured debt, and to increase tax shields/savings. The modern theory of optimal capital structure starts with the Modigliani and Miller (1958) value-irrelevance propositions. ${ }^{22}$ Although their propositions are difficult to test directly, financial innovation and structured finance in general, and particularly structured leasing, provide strong circumstantial evidence. ${ }^{23}$ Furthermore, considering that structured leasing transactions have been one of the means by which firms form their capital structures, structured leases largely affect the value of the firm. This idea was initially presented in 1963, when Modigliani and Miller, using this logic, showed that, if corporate tax is in effect, firms should use debt exclusively as a financing instrument, since this would prevent corporate tax. ${ }^{24}$ Still, this prediction did not fit well with empirical evidence, which suggests that firms typically use moderate amounts of debt. As leverage

\footnotetext{
${ }^{19}$ As in other tax-based techniques, the implementation of a structured leasing transaction is more important when the value of the asset is large and allows for a potentially greater appropriation of tax benefits.

${ }^{20}$ Some authors study the debt versus leasing decision. See, e.g., Ang and Peterson (1984), Marston and Harris (1988), Lewis and Schallheim (1992), and Adedeji and Stapleton (1996), Mehran et al. (1999), and Beatti et al. (2000).

${ }^{21}$ Altamuro (2006) presents the following three major benefits to lessees using synthetic leases: $(i)$ the ability to finance $100 \%$ of the purchase price of the asset; (ii) providing favorable financing taxes vis- $a$ vis traditional debt financing; and (iii) generating financial reporting benefits - as the synthetic lease is an off-balance sheet transaction, neither the asset nor the related liabilities are reported in financial statements.

${ }^{22}$ Harris and Raviv (1991) provide a relatively comprehensive review of the theoretical and empirical literature related to capital structure. Myers (2001) and Barclay and Smith (2005) provide a more up-todate discussion of the principal theories and empirical findings.

${ }^{23}$ Interesting studies on both theoretical and empirical literature in relation to structured finance include Caselli and Gatti (2005), Davis (2005), Fabozzi, Davis, and Choudhry (2006), Jobst (2007), Cherubini and Della Lunga (2007), Fabozzi and Kothari (2007), and Criado and Rixtel (2008).

${ }^{24}$ The value of a levered firm would equal the value of an unlevered firm plus the tax benefit associated with debt financing.
} 
increases, there is an increase in the likelihood of financial distress and bankruptcy, and this should reduce the use of debt relative to equity financing [Myers (1984)]. ${ }^{25}$ However, SPVs involved in structured leasing transactions have capital structures with higher leverage ratios than those of public companies; i.e., structured leasing transactions are characterized by their intensive use of debt.

Several authors argue that tax considerations is an important factor in the choice between debt and leasing, because leasing provides the option of 'selling' tax allowances to a lessor, in exchange for lower rental payments [e.g., Lewellen et al. (1976), Myers et al. (1976), and Beattie et al. (2000)]. Regarding structured leases, Caselli (2005) and Fabozzi et al. (2006) present the capture of tax benefits (including cross border tax loopholes) ${ }^{26}$ as a major reason for sponsors choosing this type of financing transaction. As pointed out by Caselli (2005), “... the tax variable becomes a powerful tool for creating economic maneuvering room to reduce the cost of capital for its users." Capturing tax benefits means taking advantage of the differences in taxation between leasing and other forms of financing, with the aim of reducing lessee's cost of capital. Empirically, Slovin et al. (1990) study the impact on share prices of announcements of sale-and-leasebacks. They show that this type of transactions enhance lessee value but have no significant effects on lessors. ${ }^{27}$ Fowkes (2000) analyses the use of leasing in project financing and argues that lease finance can provide sponsors with significant accounting earnings and tax benefits. $^{28}$

The fourth economic motivation refers to maintaining the sponsors' financial flexibility, by improving or maintaining financial ratios. Comparing leasing with purchasing using borrowed funds, Fabozzi et al. (2006) present the credit capacity preservation as a motivation for selecting structured leasing. According to reporting standards for leases, a capital lease - a lease that transfer substantially all of the benefits and risks incident to ownership of property, should be accounted for as the acquisition of an asset and the incurrence of an obligation by the

\footnotetext{
${ }^{25}$ The so-called trade-off theory of capital structure [Myers (1984)]. This theory has been criticized based on a set of arguments which resulted in the development of alternative theories [see Kim (1989) for a survey of this literature]. Other theories were based on asymmetric information [Jensen and Meckling (1976), Myers (1977), and Green (1984)] and signaling [Ross (1977), Myers and Majluf (1984), and Brennan and Kraus (1987)].

${ }^{26}$ Cross border leases are deals that are structured in a way that they take advantage of tax benefits in a country other than that in which the transactions takes place. This is achieved by using a vehicle company domiciled in other country, which assumes the role of lessee and them proceeds to rent the underlying asset to the effective lessee.

${ }^{27}$ In a sale-and-leaseback transaction, a firm sells an asset it owns to another entity and at the same time leases it back from the new owner (the lessor). The lessor obtains the benefits from ownership, namely: depreciation allowances and tax credits. According to Slovin et al. (1990), the principal motive for such transactions is the "... potential for differences in applicable tax rates for lessees and lessors to create value enhancement."

${ }^{28}$ The author presents four motivations for combining leasing and project financing: (i) leasing may provide off-balance sheet treatment; (ii) leasing can provide improvement in earnings; (iii) leasing may allow a sponsor to maximize the tax benefits associated with ownership of the assets; and (iv) a true leasing may provide an alternative source of funding at a lower cost.
} 
lessee (FASB Statement No. 13) - has to be capitalized as a liability and the equipment recorded as an asset on the balance sheet. Conversely, operating lease is not capitalized, and thus preserves credit capacity - the debt-to-equity ratio will be lower. Most long-term leases are structured to achieve the classification of operating leases for accounting purposes, and thus treated as off-balance sheet financing, which allows the lessee to preserve financial ratios.

Focusing on synthetic leases, Weidner (2000) argues that these transactions improve balance sheet and ratios from which businesses are judged. When a lease is classified as an operating lease, the lessee does not depreciate the asset. This favorably impacts the price-toearnings ratio and the earnings-to-assets ratio. Similarly, Sandler (2000) presents the following benefits of off-balance sheet lease financing: (i) reduction in leverage ratio; (ii) increase in return on assets; (iii) increase in earnings and cash flows; (iv) increase in tax deductions for long-life assets; and $(v)$ the ability to generate additional earnings from reinvestment of capital otherwise invested in leased assets.

Additionally, structured leasing transactions allow sponsors to improve risk management. Caselli (2005) points out the risk transfer and risk management of the asset as one of the most important factors that stimulate the demand for this type of transactions. A structured lease (leverage lease or synthetic lease) is based on the establishment of an SPV exclusively for the transaction, which works as a key risk management device. ${ }^{29}$ In both structures - the SPV acts as an owner (leverage lease) or as a lessor (synthetic lease) of the assets - off-balance sheet operating lease treatment for the lessee under FAS 13 is achieved [Fowkes (2000)]. Contrary to a synthetic lease, in a leveraged lease all of the risks are substantially transferred to the lessor. For tax purposes, a synthetic lease is structured so that the lessee may reclaim that it is, in substance, the owner of the encumbered property.

Finally, Fabozzi et al. (2006) present financial flexibility via working capital protection and fewer restrictions on management as important factors that stimulate the demand for structured leasing transactions. According to the authors, one of the advantages of leasing against borrowing to purchase equipment is that “... a lease agreement typically does not impose financial covenants and restrictions on management." Regarding working capital protection, contrary to borrowing money to purchase equipment, leasing usually provides an amount equal to the entire price of the equipment. In addition, costs incurred to acquire the equipment (e.g., delivery and installation charges) can be included in a lease agreement.

\footnotetext{
${ }^{29}$ With a leveraged lease, which is structured as a lease for tax purposes, the tax benefits of depreciation and interest deduction are retained by the lessor but partially passed back to the lessee through lower rents. A synthetic lease is an operating lease for accounting purposes but structured as financing for tax purposes.
} 


\section{Problems Related to the Use of Structured Leases}

Although all of the above-mentioned economic advantages, structured leasing also has problems, especially when used inappropriately. Considering the available literature in the field of structured leasing, we have identified the following problems related to the use of structured leasing transactions: (i) complexity; (ii) off-balance sheet treatment; (iii) higher transaction costs; and (iv) Wealth Expropriation.

According to Caselli and Gatti (2005) and Fabozzi et al. (2006), structured leasing transactions are fairly complex and involve a significant amount of cash flow evaluation, due diligence, negotiation, and legal procedures. It is commonly agreed that structured leasing instruments are complex vis-a-vis straight leasing transactions. The risk and return evaluation of a structured leasing transaction requires modeling the risk of the underlying asset(s) and cash flows, which can be particularly difficult if the asset pool is composed of heterogeneous assets. Additionally, it is necessary to evaluate the deal's specific features, including how the cash flows will be distributed to the tranches or loans, the main covenants presented in the transaction, the rights and duties of various parties involved, and the elected credit enhancement mechanisms. Consequently, structuring such a deal is more costly than corporate financing.

Another common problem relates to the fact that many structured leasing transactions are limited-recourse rather than nonrecourse, and thus there is a potential grey area in which accounting rules allow off-balance sheet treatment, but there is nonetheless some contingent liability to the sponsors. The off-balance sheet treatment is a key concept when we are referring to structured leasing. However, the terms nonrecourse and off-balance sheet should remain synonyms, which does not always happen. Only liabilities having effective no recourse to company's shareholders can justly be treated as off-balance sheet. The ability to finance a corporation off-balance sheet by issuing structured securities starts, not with finance, but with legal procedures. As asserted by Rutledge and Raynes (2010), “... unlike the economics analysis underlying off-balance-sheet finance, which is internally consistent because it is mathematical, the legal theory of off-balance-sheet finance has yet to be formalized. The law is piecemeal, relatively unexamined and disconnected from the economics." Fabozzi et al. (2006) issue a warning related to the use of structured lasing, namely the use of SPVs to manipulate accounting statements and commit fraud, and to reduce transparency and disclosure. Even in the absence of fraud, the transfer of assets to SPVs may mislead investors as to the extent of nonrecurring earnings or deferred losses.

According to Caselli and Gatti (2005), the most commonly mentioned disadvantages of structured leases are the costs of opacity related to the identification of whose balance sheet (lessor or lessee) does some leased assets append? For example, synthetic leases are operating leases for accounting purposes and financing operations for tax purposes; i.e., they are offbalance sheet leases, in which the lessee remains the owner of the financed assets and retains the 
tax benefits associated with ownership, while simultaneously enjoying the benefits of an operating lease - the lessor offers the lessee a lower lease rate because the equity investor passes a portion of his tax benefit back to the lessee in the form of reduced lease payments. Another example is the leverage lease. For financial accounting purposes, a leverage lease (operating lease) is not disclosed in the lessee balance sheet as financial obligations; i.e., the lease equipment is not capitalized and the lease obligation is not shown as a liability on the balance sheet.

Regarding transaction costs, Caselli and Gatti (2005) argue that one of the major disadvantages of structured leases are the costs of complexity. This idea is corroborated by Fabozzi et al. (2006), who state that a structured lease is similar to a single-investor lease - in terms of equipment selection and negotiation (rentals, options, responsibility for taxes, insurance, and maintenance) - but appreciably more complex in size, documentation, legal involvement, and, most importantly, in the number of parties involved and the unique advantages that each party gains.

Miller and Upton (1976) conclude that no financial advantages accrue from leasing. Lewellen et al. (1976) and Myers et al. (1976) argue that, under a set of assumptions, there is a potential for gains in valuation for the firm involved in leasing, resulting from tax benefit expropriation (government bears a loss in taxes). According to Altamuro (2006), critics of structured leases argue that the economic benefits of these off-balance sheet transactions "... are the result of short-sighted opportunistic behavior by managers that lead to wealth extraction at the expense of other groups of stakeholders." Finally, some authors [e.g., Wanzenboeck (2001)] argue that, in cross-border leasing, the wealth expropriation phenomenon is greater, essentially when the leasing is structured based on the interposition of a trust between the lessor and lessees. In this case, the tax benefits produced are duplicated.

\section{The Structured Leasing Market}

The review of factors underlying the growth of the leasing market highlighted the centrality of taxation. With structured leasing, lessees can use tax benefit in the most appropriate manner to achieve their economic and financial objectives. The regulatory framework is crucial when we are dealing with this type of transactions. Thus, understanding the tax framework in force in the country concerned allows the perception of economic maneuvering room of structured leasing. In Europe, the regulatory framework is quite well-defined and stable.

There are three macro-trends helping to explain the structured leases' market evolution: (i) tax regime - a significant change in tax framework (at home and overseas) strongly increases or decreases the size of the market; (ii) private banking and family office - the growth of the real estate leasing market is highly driven by these operators, who manage real estate investment portfolios; and (iii) international and synthetic-type transactions. 
The effective match between the leasing instrument and requirements of large real estate deals (in developing countries and others too) is a factor representing a substantial and structural stimulus for market growth. 


\section{Bibliography}

Adedeji, A., and R. Stapleton, 1996, "Leases, Debt, and Taxable Capacity", Applied Financial Economics, Vol. 6, pp. 71-83.

Altamuro, Jennifer (2006), "The determinants of synthetic lease financing and the impact on the cost of future debt", SSRN Electronic Paper Collection.

Amembal, Sudhir (2000), International Leasing Puzzle: The Complete Guide, Salt Lake City, Utah: Amembal \& Associates.

Ang, J., and P. Peterson, “The Leasing Puzzle”, Journal of Finance, Vol. 39, No. 4, pp. 10551065.

Barclay, M., and C. Smith (1995), "The Maturity Structure of Corporate Debt", Journal of Finance, Vol. 50, No. 2, pp. 609-631.

Barclay, M., and C. Smith (2005), "The Capital Structure Puzzle: The Evidence Revisited", Journal of Applied Corporate Finance, Vol. 17, No. 1, pp. 8-17.

Baron, David (1974), "Default Risk, Homemade Leverage, and the Modigliani-Miller Theorem", American Economic Review, Vol. 64, No. 1, pp. 176-182.

Baron, David (1976), "Default Risk and the Modigliani-Miller Theorem: A Synthesis", American Economic Review, Vol. 66, No. 1, pp. 204-212.

Beattie, V., A. Goodacre, and S. Thomson (2000), "Operating leases and the assessment of lease-debt substitutability", Journal of Banking and Finance, Vol. 24, No. 3, pp. 427470 .

Boobyer, Chris (2003), Leasing and Asset Finance, London: Euromoney Publications, $4^{\text {th }}$ edition.

Bower, Richard (1973), "Issues in Lease Financing", Financial Management, Vol. 2, No. 4, pp. 25-34.

Braund, Steven (1989), "Leasing - A Review of the Empirical Studies", Managerial Finance, Vol. 15, pp.13-20.

Brealey, R., and C. Young (1980), "Debt, Taxes and Leasing: A Note", Journal of Finance, Vol. 35, No. 5, pp. 1245-1250.

Brennan, M., and A. Kraus (1987), "Efficient Financing Under Asymmetric Information", Journal of Finance, Vol. 42, No. 5, pp. 1225-1243.

Brick, I., W. Fung, and M. Subrahmanyam (1987), "Leasing and Financial Intermediation: Comparative Tax Advantages", Financial Management, Vol. 16, No. 1, pp. 7-14.

Carretta, A., and G. De Laurentis (1998), Il manual del leasing, Egea: Milan.

Caselli, Stefano (2005), "Structured Leasing Transactions", in Structured Finance: Techniques, Products and Market, Stefano Caselli and Stefano Gatti (editors), pp. 96-137, Berlin: Springer.

Caselli, S., and S. Gatti (2005), Structured Finance: Techniques, Products and Market, Springer Berlin.

Cherubini, U., and G. Della Lunga (2007), Structured Finance, the Object Oriented Approach, John Wiley \& Sons, Inc.

Criado, S., and A. Rixtel, 2008. Structured Finance and the Financial Turmoil of 2007-2008: An Introductory Overview, Bank of Spain Occasional Paper No. 0808.

Davis, Henry (2005), "The Definition of Structured Finance: Results from a Survey", The Journal of Structured Finance, Vol. 11, No. 3, pp. 5-10. 
Deo, Prakash (2009), "A Spreadsheet Model for Domestic Leveraged Leases", The Journal of Structured Finance, Vol. 15, No. 1, pp. 118-131.

Eisfeldt, A., and A. Rampini (2009), "Leasing, Ability to Repossess, and Debt Capacity", Review of Financial Studies, Vol. 22, No. 4, pp. 1621-1657.

Fabozzi, F., H. Davis, and M. Choudhry (2006), Introduction to Structured Finance, Wiley Finance.

Fabozzi, F., and V. Kothari (2007), "Securitization: The Tool of Financial Transformation", Working Paper No. 7, Yale ICF.

Fowkes, David (2000), "Leasing in Project Financing”, Journal of Project Finance, Vol. 6, No. 1, pp. 21-31.

Graham, J, M. Lemmon, and J. Schallheim (1998), "Debt, leases, taxes and the endogeneity of corporate tax status", Journal of Finance, Vol. 53, No. 1, pp. 131-162.

Green, Richard (1984), "Investment Incentives, Debt and Warrants", Journal of Financial Economics, Vol. 13, No. 1, pp. 115-136.

Harris, M., and A. Raviv (1991), "The Theory of Capital Structure", Journal of Finance, Vol. 46, No. 1, pp. 297-355.

Hellwing, Martin (1981), "Bankruptcy, Limited Liability, and the Modigliani-Miller Theorem", American Economic Review, Vol. 71, No. 1, pp. 155-170.

Jensen, M., and W. Meckling (1976), "Theory of the Firm: Managerial Behavior, Agency Costs, and Ownership Structure", Journal of Financial Economics, Vol. 3, No. 4, pp. 305-360.

Jobst, Andreas (2007), “A primer on Structured Finance”, Journal of Derivatives and Hedge Funds, Vol. 13, No. 3, pp. 199-213.

Kim, Han (1989), “Optimal Capital Structure in Miller's Equilibrium”, in Financial Markets and Incomplete Information: Frontiers of Modern Financial Theory, Sudipto Bhattacharya and George Constantinides (editors), Vol. 2, Totowa, N.J.: Rowman and Littlefield.

Krishnan, V., and R. Moyer (1994), "Bankruptcy Costs and the Financial Leasing Decision", Financial Management, Vol. 23, No. 2, pp. 31-42.

Lewellen, W., M. Long, and J. McConnell (1976), "Asset Leasing in competitive capital markets", Journal of Finance, Vol. 31, No. 3, pp. 787-798.

Lewis, C., and J. Schallheim (1992), “Are Debt and Leases Substitutes?”, Journal of Financial and Quantitative Analysis, Vol. 27, No. 4, pp. 497-511.

Marston, F., and R. Harris (1988), "Substitutability of leases and debt in corporate capital structures", Journal of Accounting, Auditing and Finance, Vol. 3, pp. 147-170.

Mehran, H, R. Taggart, and D. Yermack (1999), "CEO Ownership, Leasing, and Debt Financing", Financial Management, Vol. 28, No. 2, pp. 5-14.

Miller, M., and C. Upton (1976), "Leasing, buying, and the cost of capital services", Journal of Finance, Vol. 31, No. 3, pp. 761-786.

Modigliani, F., and M. Miller (1958), "The Cost of Capital, Corporation Finance and the Theory of Investment", American Economic Review, Vol. 48, No. 3, pp. 261 - 297.

Myers, Stewart (1977), "Determinants of Corporate Borrowing", Journal of Financial Economics, Vol. 5, No. 2, pp. 147-175.

Myers, Stewart (1984), “The capital structure puzzle", Journal of Finance, Vol. 39, No. 3, pp. 1005-1037. 
Myers, Stewart (2001), "Capital Structure”, Journal of Economic Perspectives, Vol. 15, No. 2, pp. 81-102.

Myers, S., D. Dill, and A. Bautista (1976), "Valuation of financial lease contracts", Journal of Finance, Vol. 31, No. 3, pp. 799-819.

Myers, S., and N. Majluf (1984), "Corporate financing and investment decisions when firms have information that Investors do not have", Journal of Financial Economics, Vol. 13, No. 2, pp. 187-221.

Ross, Stephen (1977), “The Determination of Financial Structure: The Incentive Signalling Approach", Bell Journal of Economics, Vol. 8, No. 1, pp. 23-40.

Rutledge, A., and S. Raynes (2010), Elements of Structured Finance, New York: Oxford University Press.

Sandler, Gil (2000), "Off-Balance Sheet Lease Financing: An Overview", The Real Estate Finance Journal, Spring, pp. 66-71.

Shank, I., and A. Gough (1999), Equipment Leasing/Leveraged Leasing, $4^{\text {th }}$ edition, New York: Practising Law Institute.

Slovin, M., M. Sushka, and J. Polonchek (1990), "Corporate Sale-and-Leasebacks and Shareholder Wealth”, Journal of Finance, Vol. 45, No. 1, pp. 289-299.

Smith, C., and J. Wakeman (1985), "Determinants of corporate leasing policy", Journal of Finance, Vol. 40, No. 3, pp. 895-908.

Stiglitz, Joseph (1969), "A Re-Examination of the Modigliani-Miller Theorem", American Economic Review, Vol. 59, No. 5, pp. 784-793.

Stiglitz, Joseph (1974), "On the Irrelevance of Corporate Financial Policy”, American Economic Review, Vol. 64, No. 6, pp. 851-866.

Wanzenboeck, Franz (2001), "U.S. Cross-Border Leases as a Tool for Corporate Finance", SSRN Electronic Paper Collection.

Weidner, Donald (2000), "Synthetic leases: Structured finance, financial accounting and tax ownership", The Journal of Corporation Law, Vol. 25, pp. 447-470.

Williamson, Oliver (1988), "Corporate finance and corporate governance", Journal of Finance, Vol. 43, No. 3, pp. 567-591. 